\title{
Variety of Rice-Field Lexicons From Luhak to Rantau
}

\author{
S Ladyanna ${ }^{1}$, R Almos ${ }^{2}$ \\ ${ }^{1,2}$ Andalas University \\ \{1sonezzaladyanna@hum.unand.ac.id 2ronaalmos@hum.unand.ac.id\}
}

\begin{abstract}
The character of soil fertility in most parts of Indonesia, especially the Minangkabau Cultural area, is growing and developing supporting rice cultivation in rice fields. The lexicons and local wisdom of the community grow in harmony with the dynamics of the activities of the community's rice fields, so that customs and traditions emerge that coexist with the philosophy of rice and natural activities. In this article, it is explained about the variations in the lexicon of rice fields in the luhak and rantau regions in Minangkabau culture and their relation to local wisdom. The method used in this study is qualitative research. Data collected through the method refer to the interview technique. The informants of this study were local Minangkabau farmers and community leaders. Other data sources are text edits and fochlor documentation. Data analyzed through anthropolinguistic theory. The results of the study are presented in the form of scientific articles. It can be concluded that there are variations in the lexicon of rice fields in Minangkabau culture in the luhak and rantau regions. In each lexicon and variations that exist contain local wisdom values of classical Minangkabau people in general. Preservation of the knowledge of the classic lexicon in the millennial generation is an important step in maintaining values in a culture that is important for guiding life and facing nature.
\end{abstract}

Keywords: Lexicon Variations, Rice Fields, Luhak Rantau

\section{INTRODUCTION}

Rice fields are the core of agriculture in Indonesia because most Indonesian people make rice as a staple food in addition to other agricultural products [1]. The character of soil fertility in most parts of Indonesia, especially the Minangkabau Cultural area, is growing and developing supporting rice cultivation in rice fields. The proverb and local wisdom of the community grows in line with the dynamics of the activities of the rice fields of the community so that customs and traditions emerge which live side by side with the philosophy of rice and natural activities [2] .

In Minangkabau culture, civilized life of the community is compared with the traditional proverb that uses natural and agricultural based lexicons, such as in the quote bumi sanang padi manjadi, padi masak jaguang maupiah, anak buah sanang santoso, taranak bakambang biak, bapak kayo mande batuah, mamak disambah urang pulo which means togetherness and prosperity [3]. Welfare is measured by abundant agricultural products, especially rice. If harvested rice plants are abundant, life will not experience difficulties. Therefore, for the classic Minangkabau community, ka sawah (farming in the fields) is an important thing to continue to support the family in addition to trading. 
Thus, the rice lexicon has meaning and also some of it has meaning that implies the local wisdom of the community [4]. Research on lexicons in relation to anthropolinguistic studies is an important step in the preservation of the values of local wisdom of a society because the development of the times alienates people from classical civilization. This resulted in a decline in people's knowledge of the lexicon so that the meanings of traditional advice were not conveyed in depth.

Based on these results, a study of the lexicon of rice fields in Minangkabau culture is important to develop. Given the Minangkabau cultural area has a division of territory with respect to culture, hypothesized lexicons will vary. Each variation of course reflects the typical local wisdom of a region. Therefore, in this article, a study of the lexicon variation of rice fields will be based onluhak and rantau regions .

Luhak is the core area of Minangkabau. There are three luhak areas in Minangkabau, namely Luhak Tanah Datar, Luhak Agam and Luhak Limo Puluah Kota [5] . It was in this area that the Minangkabau people first established koto, hamlet, nagari sam $\mathrm{p}$ a the last became luhak. Rantau is an area where Minangkabau people seek fortune and settle in the area. in the seas, Minangkabau people are looking for income and business. After succeeding in the rantau area they succeeded, they will return to the village to build a yard.

So in this article, it is explained about the variations in the lexicon of rice fields in the luhak and rantau regions in Minangkabau culture and their relation to local wisdom . Research on the rice lexicon has been carried out by Ladyanna and Rona Almos, but only in one area, namely in the city of Padang as the capital of West Sumatra Province in the context of ecolinguistic studies(Ladyanna, Sonezza; Almos, Rona; Hidayat, Herry Nur; Seswita;) . Ladyanna, $p$ Changes et al stated that technology does not lead to any change but the limited paddy fields due to demographic dynamics resulted unusual lexicon of rice fields again for the younger generation so feared inheritance will break if there is no inventory in the form of print and electronic media. In another reference, Ladyanna et al. Stated that rice lexicons must be inventoried so that the lexicon inheritance can continue to be carried out so that the local wisdom of the lexicon can be maintained in the next generation. (Ladyanna, Almos and Hidayat) .

From the two references, the research was only conducted in the city of Padang and only in the context of ecolinguistic studies. Therefore, the writing of this article is important to continue to develop research in the field of rice lexicons so that the retention of regional languages which are the staple in preserving the inheritance of local wisdom knowledge - can continue. -- connect because you connect-- Anthropolinguistic studies are interdisciplinary knowledge between anthropology and language. anthropolinguistics is the study of interdisciplinary disciplines which further explore language to find cultural understanding (cultutal understanding) [6] . According to Palmer [7] anthropolinguistics is a name that tends to contain broad meanings in terms of language and culture. From the explanation above we can draw a conclusion that the relationship between language and culture cannot be separated from each other because language is the first culture that isacquired by humans.

\section{RESEARCH METHOD}

This research is a qualitative research. Sources of data from this study are primary and secondary sources. Primary data is collected through the method refer to by interviewing informants. The informants of this study were local Minangkabau farmers and community leaders who were part of the Minangkabau adat institution called Kerapatan Adat Nagari (KAN). The farmers in question are Minangkabau people with a age of more than 50 
years. Secondary data sources from this study were text edits and foclor documentation. Thus, the data is expected to be complete and saturated.

Then, the data is analyzed using the equivalent and final method through anthropolinguistic theory. The equivalent method used is the equivalent method proposed by Sudaryanto [8] . First, using the translational method translates Indonesian. Next, a referential equivalent method is performed to see the reference of the lexicon. Then, it is analyzed by the agih method to compare with the lexicon from other regions if there is a difference. In the end, it will be studied in the context of anthropolinguistic studies. Finally, the results of the study are presented in the form of scientific articles.

\section{RESULT AND DISSCUSSION}

In essence, rice field activities in classical Minangkabau culture have similarities. However, differences were found in the activity of removing rice grains from rice stalks. For the rantau region and most of the luhak region, malambuik lexicon is used. Meanwhile, some areas in the Luhak region use the mairiak lexicon. This difference shows differences in the culture of society in carrying out an activity even though the community is in an umbrella of the same culture that is Minangkabau culture.

In addition, there were also differences in the amount of rice harvested before the use of the "sack" karuang lexicon. In the rantau region, use of gantang found, and belek; while in the area of Luhak other variations were found beside the gantang and belek namely bak and padi. This also shows that there is an increasingly oppressed variation in the use of the word "sack" and the dose with the international system that has been used recently. Here's the full description.

\subsection{Between Malambuik and Mairiak}

One of the important activities during the harvest is the activity of releasing rice grains from the stem. When rice grains are released from the stem, the amount of the harvest is ready to count. That is, how much zakat must be issued, how much will be obtained by the owner of the rice fields, field workers, and other involved parties can be immediately calculated; or how much is obtained by each farmer. There are two lexicons for releasing rice grains from the stem, namely malambuik and mairiak.

Before the explanation of these two lexicons, it will first be explained about the management of land management in the classic Minangkabau community. First, paddy fields are carried out by land owners who are usually a people. In these people, paddy fields are worked together with a proportional division of labor. Men will work on land cultivation that requires great energy such as plowing and hoeing. Women will work on activities that are not very energy intensive, such as planting seeds that have been sown and cutting rice during harvest.

The second management is the processing of land by a second party with a profit sharing system. Generally, rice fields are carried out by other people and the yield will be divided proportionally. This division depends on the investment system during farming. If the landowner does not incur any costs - all the costs of farming are borne by the farmer - then the landowner only gets one third of the harvest. However, if all costs are borne by the land owner, then the yield will be divided in half after all costs have been incurred.

Both systems will influence community involvement when releasing rice grains from the stem. However, this activity is still carried out together, in mutual cooperation. Malambuik in 
the form of throwing rice stalks into a tool repeatedly until the rice grains are all released. The bottom of the tool is made of uneven wood, made like a tiered. Then, the top is covered with cloth or trepal so that the rice is not thrown out. One bunch of rice stalks is held by one adult and thrown several times into the tool.

When one person or a few people doing this malambuik activities, other members can do other things like continue to harvest rice, or set up to count the number of harvested container. In fact, if not many family members or farmers can come at harvest time, rice grains can still be released from the stalks. This activity does not require many people. However, it can cause disruption to breathing because when the rice stalk is knocked down it will certainly cause dust from small particles that are on the rice stalk or also called miang. Generally, the farming community in the rantauarea uses this system and also some people in the Luhak area, some use Malambuik.

Another lexicon, Mairiak, is found in the Luhak Agam region. Some adults will stand on rice and will move the soles of the feet together so that the rice grains are released from the stem. This activity requires solid legs and the right techniques, and solid teamwork. In this activity one stick is needed which is made of small bamboo which functions as a barrier and balancing body. While mairiak, social interactions are interwoven. This activity reflects the social system of the Minangkabau community which is thick with a communal system, living in groups. Dependence between members of a people is the key to the success of these people.

Both of these systems began to be abandoned by farmers because of the presence of more modern rice grains with machines. Nonetheless, these two lexicons are night and day and still used.However, the lack of interest in the younger generation in agriculture resulted in the lexicon being no longer known to many millennial generations. Ignorance of a lexicon indicates a decline in understanding local wisdom in the younger generation.

So, the lack of souls of the people and the lack of dependence among members of the people who will give birth to the low soul of brotherhood is a real consequence as a result of the decline in understanding a culture. In a culture, local wisdom saves the values of life that will be very beneficial in living life and facing the symptoms of nature. These two lexicons hold the value of a cultural philosophy regarding teamwork and management systems. The lack of knowledge about lexicons is feared to decrease moral and cultural values in future generations.

\subsection{Enchanters Amount of Harvested Rice}

The classic lexicon found in connection with the takers for the amount of rice harvested includes bak,padi, gantang and belek. After fertilizing industrial products began to be marketed to farmers, farmers began counting with a sack system guided by sacks issued by fertilizer producers, namely Pusri (Pupuk Sriwijaya) which is equivalent to $50 \mathrm{~kg}$.

Based on the results of research in Luhak nan Tuo, namely Tanah Datar District, it was found that the use of bak and padi. One bak is equivalent to $40 \mathrm{~kg}$. One thousand padi is equivalent to 33 bak or 1,320 kg. The use of bak and padi has been abandoned by the community because the scales have been easily obtained. However, this makes the community dependent on a scale tool which can sometimes also experience damage or fraud that can harm one party and cause conflict.

Next, there's a gantang lexicon and belek. For other regions, in particular rantau, generally using gantang and belek. One gantang has sometimes different measurements in different regions. One gantang in Tuo is equivalent to approximately $1.3 \mathrm{~kg}$. Likewise, belek has begun to be used after the paint has circulated in the community. Initially, the paint was packed in rectangular aluminum cans. One belek is equivalent to 15 gantang or approximately 19-20 
$\mathrm{kg}$. To avoid disputes due to heavy depreciation of rice, one sack is considered to be equivalent to 3 belek.

When rice is harvested, of course, it still has more water content than after being dried. If a gram system is used in accordance with international standards it will cause confusion in the amount of rice during the drying process. Therefore, the classic Minangkabau community does not use the gram (kilogram) system. In the process of rice cultivation in Minangkabau culture, there are variations in the lexicon that represent different activities between Minangkabau people in luhak and rantau, namelymairiak and malambuik. Mairiak is used by the Minangkabau people in luhak, especially Luhak Agam and malambuik are used by the Minangkabau people in darek - some luhak areas also usemairiak. The two lexicons contain local wisdom about mutual cooperation and the spirit of brotherhood in the Minangkabau community. Nelfi and Faith Laili also stated that rice cultivation activities in Minangkabau contained mutual cooperation and brotherhood values, but some language expressions for this matter began to diminish so that the value of mutual cooperation and brotherhood contained in the expressions also faded. [9] .

Likewise in the case of classifier, found bak and padi as penyukat in the luhak area beside the gantang and sukek as in the rantau region. In addition, there are also sumpik and bangkiah lexicons [10]. The use of these lexicons contains local wisdom to reduce conflict in the community because the newly harvested rice has a different mass from the rice that has been dried in the sun associated with the water content of the rice. Therefore, the use of heavy doses with international standards (ie Gram) can lead to confusion in the calculation of the number of crops so that it can cause negative prejudice and eventually lead to conflict in the community.

Research on rice fields and culture is a study that must be developed in order to map the cultural philosophy of the community, especially the region that makes rice the main staple food.Many researches on rice fields are carried out, but with regard to language and culture not so much while the efforts of millennial era cultural inheritance must be supported by scientific documents[11] . Other studies regarding lexical variation were carried out by Sugart but Sugart only examined lexical variations for rice in Asia and how independent the lexicon was [12] [13] . Thus, research on rice lexicon is important to be developed to preserve the values of local wisdom of a culture.

\section{CONCLUSION}

It can be concluded that there are variations in the lexicon of rice fields in Minangkabau culture in the luhak and rantau regions. For the rantau region and most of the luhak region, malambuiik lexicon is used. Meanwhile, some areas in the Luhak region use the mairiak lexicon. This difference shows differences in the culture of the community in carrying out an activity even though the community is in an umbrella of the same culture.

$\mathrm{P}$ difference in the amount of rice harvested before using the "sack" karuang lexicon. In the rantau region, use of gantang was found, and belek; while in the area of Luhak other variations were found beside the gantang and belek namely bak and padi. This also shows that there is an increasingly oppressed variation in the use of the word "sack" and the dose with the international system that has been used recently.

Each lexicon and variations of the lexicon contains the values of local wisdom classic Minangkabau society. Preservation of the knowledge of the classic lexicon in the millennial generation is an important step in maintaining values in a culture as a guide to life and facing nature. 


\section{REFERENCES}

[1] B. University of California, "No Title," Arts Midwest World Fest, 2012. [Online]. Available: http://www.artsmidwestworldfest.org/sites/default/files/study_guide_guides/indonesiacountry-and-culture.pdf.

[2] Hasanuddin-WS, "The Intangible Cultural Heritage of Minangkabau Traditional Expressions: The Local of the Society in Advising and Noble Advicing," Hum Sciences. , vol. 2, pp.131-141, 2016.

[3] Discourse, "The Nan Sakato Society, The Life View of the Minangkabau People," 2014. [Online]. Available: http://www.wacana.co/2014/03/masyarakat-nan-sakato-pandanganhidup-orang-minang/.

[4] S. Ladyanna, R. Almos, HN Hidayat, and Seswita, "Lexicon of Rice Fields in Padang City," Puitika, vol. 14, 2018.

[5] P. Batara, "Luhak; Regional Division in the Minangkabau Community, "2013. [Online]. Available: http://www.wacana.co/2013/08/luhak-minang/.

[6] R. Almos and D. Pramono, "Ethnomedical Lexicon in Traditional Minangkabau Medicine," J. Arbitrer, vol. 2, no. April, pp. 44-53, 2015.

[7] Palmer, Toward a Theory of Cultural Linguisyics . Austin: University of Texas Press, 1996.

[8] Sudaryanto, Methods and Various Language Techniques. Yogyakarta, 1993.

[9] E. Nelfi and Iman Laili, "The expressions of Planting The Rice in the Paddy Procession in the Minangkabau Society as one of the Pillars of Culture and character of the Nation," 2014. [Online]. Available: http://ejournal.unp.ac.id/index.php/isla/article/view/5320.

[10] Ike Revita, "Said Penyukat in Minangkabau," the humanities , vol. 18, 2006.

[11]J. Whitman, "Northeast Asia Linguistic Ecology and the Advent of Rice Agriculture in Korean and Japan," $2008 . \quad$ [Online]. Available: https://pj.ninjal.ac.jp/languagedispersal/Whitman2012Rice.pdf.

[12] K. Saddhono, "Language and superdiversity: Indonesians knowledging at home and abroad. By Zane Goebel." Soc. Stu. vol. 12 no.1 pp. 113-118, 2018

[13]Laurent Sugart, "How Many Independent Rice Vocabularies in Asia ?," 2011. [Online]. Available: https://hal.archives-ouvertes.fr/hal-00651427/document. 